\title{
Mejorar las habilidades de lectura a través de la estrategia de círculos literarios en estudiantes EFL
}

\section{Enhancing reading skills through literary circles strategy in EFL students}

1 Renato Emanuel Bautista Ullauri

(iD) https://orcid.org/0000-0002-3889-5992

Universidad Técnica de Ambato, Facultad de Ciencias Humanas y de la Educación,

Ambato, Ecuador

renato.bautista.1992@outlook.es

2 Andrea Karina Carvajal Gavilanes

https://orcid.org/0000-0002-6813-9936

Universidad Técnica de Ambato, Facultad de Ciencias Humanas y de la Educación,

Ambato, Ecuador

acarvaja15121@uta.edu.ec.

3 Diego Santiago Andrade Naranjo

https://orcid.org/ 0000-0002-5536-6267

Universidad de las Fuerzas Armadas ESPE, Facultad de Ciencias Humanas y Sociales,

Latacunga, Ecuador

dsandrade3@espe.edu.ec

4 Jorge Leonardo Flores Ubidia

https://orcid.org/0000-0002-3464-7836

Universidad Técnica de Ambato, Facultad de Ciencias Humanas y de la Educación,

Ambato, Ecuador

jfloresubidia@gmail.com

Artículo de Investigación Científica y Tecnológica

Enviado: 24/12/2021

Revisado: 29/12/2021

Aceptado: 12/01/2022

Publicado:08/03/2023

DOI: https://doi.org/10.33262/concienciadigital.v6i1.4.2017

Cítese:

Bautista Ullauri, R. E., Carvajal Gavilanes, A. K., Andrade Naranjo, D. S., \& Flores Ubidia, J. L. (2023). Mejorar las habilidades de lectura a través de la estrategia de círculos literarios en estudiantes EFL. ConcienciaDigital, 6(1.4), 606-617. https://doi.org/10.33262/concienciadigital.v6i1.4.2017

CONCIENCIA DIGITAL, es una Revista Multidisciplinar, Trimestral, que se publicará en soporte electrónico tiene como misión contribuir a la formación de profesionales competentes con visión humanística y crítica que sean capaces de exponer sus resultados investigativos y científicos en la misma medida que se promueva mediante su intervención cambios positivos en la sociedad. https://concienciadigital.org

La revista es editada por la Editorial Ciencia Digital (Editorial de prestigio registrada en la Cámara Ecuatoriana de Libro con No de Afiliación 663) www.celibro.org.ec 
Palabras claves: círculos literarios, comprensión lectora, hábitos de lectura, aprender.
Keywords:

literary circles, reading comprehension, reading habits, learning.
Resumen

Introducción. Evidentemente, en un país con escasos hábitos de lectura, el uso de círculos literarios es una alternativa excepcional para inspirar a los estudiantes a leer de manera independiente y exponerlos a la lengua extranjera. Las palabras habladas y escritas son los cimientos de la vida, los niños que leen por placer todos los días no sólo rinden más en la escuela, sino que además se expresan mejor, hacen amigos y tienen ciertas habilidades clave para la vida. Objetivo. Analizar el beneficio de los círculos literarios en las actitudes lectoras de los estudiantes de EFL. Metodología. Se aplicaron métodos cuantitativos para determinar la eficacia de la investigación, así como métodos cualitativos para analizar el progreso de las competencias lectoras en los estudiantes. El tipo de investigación es experimental para lo cual se realizó a 67 estudiantes de sexto grado A y B de educación general básica. Los participantes se clasificaron utilizando la herramienta AlTzar, distribuyendo en un grupo experimental y un grupo de control. El grupo experimental fue expuesto a la estrategia de lectura dos horas por semana durante un mes. Se administró un único pre-test y posttest a toda la población como herramienta para recoger la información necesaria para el análisis correspondiente. Resultados. Al final del estudio, los resultados del post-test de los estudiantes se compararon con los resultados del pre-test mediante la prueba T Student, para luego ser contrastados con enfoques, teorías y conceptualizaciones de diferentes autores de investigaciones científicas similares que apoyaron la relevancia de la hipótesis inicial. Conclusión. La relación entre los círculos literarios en el desarrollo de las habilidades de comprensión lectora es de gran importancia ya que permite a los estudiantes aprender en un marco de comprensión de los propósitos y objetivos del texto de destino, tanto el texto escrito explícito como la información implícita y la basada en hechos de la historia.

\section{Abstract}

Introduction. Clearly, in a country with poor reading habits, the use of literary circles is an exceptional alternative to inspire students to read independently and expose them to the foreign language. Spoken and written words are the foundation of life, children who read for pleasure every day not only do better in school, but also express themselves better, make friends and have certain key life 
skills. Objective. Analyze the benefit of literary circles on the reading attitudes of EFL students. Methodology. Quantitative methods were applied to determine the effectiveness of the research, as well as qualitative methods to analyze the progress of reading skills in students. The type of research is experimental, for which 67 students of sixth grade A and B of basic general education were carried out. Participants were classified using the AlTzar tool, distributing into an experimental group and a control group. The experimental group was exposed to the reading strategy two hours a week for a month. A single pre-test and post-test were administered to the entire population as a tool to collect the information necessary for the corresponding analysis. Results. At the end of the study, the results of the post-test of the students were compared with the results of the pre-test by means of the T Student test, to later be contrasted with approaches, theories and conceptualizations of different authors of similar scientific investigations that supported the relevance of the initial hypothesis. Conclusion. The relationship between literary circles in the development of reading comprehension skills is of great importance since it allows students to learn within a framework of understanding the purposes and objectives of the target text, both the explicit written text and the implicit information and the one based on the facts of the story.

\section{Introduction}

Reading is a learning tool that allows students to have better development in society; it is the cornerstone for people's progress in life (Snow et al., 1998). Despite its importance, reading is one of the most challenging areas in the education system. The ever-increasing demand for high levels of technological society makes this issue even more pressing. The trends of globalization have driven Ecuadorians to the urge to read texts in foreign languages just as English. People must read texts in English for a variety of purposes such as in business, social, and educational settings. Business people are required to be able to read in English to have a proper comprehension of legal documents and to establish successful international relations (Allan et al., 2005). Besides, many people from other places where Spanish is not spoken visit Ecuador, so speaking and reading in English becomes a tool to communicate with foreign tourists. It is equally important that students practice reading, as it is a prerequisite for accessing many forms of knowledge which are 
published mostly in English. However, reading in English is also a must for Ecuadorians, who are looking to perfect their English for professional reasons.

The limited reading habits in the Ecuadorian culture has always been an obstacle in education, the lack of inspiration that students have for reading influences foreign language learning too. Students' academic progress is limited without skills of reading comprehension and the motivation for reading to learn (Alvermann \& Earle, 2003). Reading skills are critical to the development of individuals. They guide people towards successful lives and keep them updated on world events like new inventions or discoveries; furthermore, reading stimulates imagination, relaxation, and entertainment. Even though, teaching English as a foreign language is not a basic task, especially when referring to the improvement of the reading comprehension skills. Teachers use a variety of strategies to strengthen the development of students' reading skills. That is why this research is done, to advise teachers with a strategy to cultivate students reading skills but mainly to expand children comprehension and critical thought.

This research work was shaped considering the idea that reading is more meaningful if students have the opportunity to interact with their peers about what they read. Basically, it aims to explore how literary circles can benefit the reading attitudes of EFL students. In detail Lopez Medina (2007) mentions that literary circles could be a vehicle to facilitate students to become better readers, as well as teachers, improve their pedagogical skills. According to Medrano and Diss (2013), the work of Literature Circles is an ongoing process, the work of ongoing learning and assessment, always in concert and collaboration with others around us. Literary circles provide opportunities for students to interact and be a part of a social group. Students who master teamwork skills in school will learn to be a part of a team which is a crucial ability to have when finding a job or career in the future. As Coccia Harvey (2015), literary circles can also intrinsically motivate students to be involved in the act of reading because they are associating the method with the pleasurable act of conversation with their peers. In essence, this conceptual framework illustrates the researcher's vision based on Vygotsky conception of how children construct meaning and learn from others within a social context.

Lastly, reading skill is essential because it develops the mind, understanding the written words is one way the mind grows in its ability. Through reading stories, children are exposed to a wide range of words (Anderson \& Corbett, 2008). This helps them build their vocabulary and improve their communication and language skills, which makes a big difference to children educational performance.

\section{Methodology}

This research is experimental because the control group and the exploratory group were compared in all respects except in the application of the treatment, and any difference in 
measurements that is found between them can be attributed only to the treatment (Mildner Ball, 2019). Equally, this research employed a qualitative-quantitative mixed approach to analyze how the use of literacy circles can enhance the reading comprehension skills in EFL children. It is qualitative because it produced descriptive data: people's own words, spoken or written, and observable behavior and also quantitative since it relies on numerical measurement, counting, and using statistics to establish exact indicators. In the same token, this research proposed a bibliographic procedure to check assumptions, clarify orientation, and redirect the stagnant fields.

The present study was conducted on a population of 67 students, all of whom are at the same English school level. For the purposes of the study, the total population was divided as follows: The total population was distributed into two groups of 29 and 38 students. From this subdivision, each group of 29 and 38 students were selected to form two subgroups called: "Control Group" and "Experimental Group".

The control group is a group of study to which only the level of knowledge of the English language is measured, through a reading comprehension skills test and without interfering at any time in the learning of the students. The experimental group represents the opposite. This group of students is supposed to measure the level of knowledge of the English language, with the difference that this group is monitored and subjected to a new teaching methodology to improve their level of understanding of the English language.

In both cases, to determine a before and after: a diagnostic test was taken at the beginning of the research, and at the end of it. Thought these interventions, it can be observed if the control group from beginning to end and without any type of intervention had an improvement in the English language; in the same way, it decided whether the experimental group had some improvement from beginning to end of the study but with the application of the new teaching methodology.

Furthermore, in order to analyze the data collected, it is necessary to use a statistical test that allows this purpose to be carried out. For the present study, the T Student test for related samples was used, since this statistical test facilitates the analysis of data from the same sample before applying a study on this sample and after applying the study on the same sample. This is because it identifies the existing variation through the means of the data obtained, which determines whether the study applied has been successful or not (Porras Velazquez, 2017).

For a statistical test to be applied, the instrument must be validated. Validating an instrument allows us to identify that the data have the same distribution and that when applying the test, the data can be proved and real. In this case, the Shapiro Wilk validation test was used, which allowed us to determine whether the data studied correspond to a 
normal distribution in obtaining the arithmetic means, which are necessary to apply the $\mathrm{T}$ Student test (Marshall \& Balnton, 2006).

Once the statistical analysis was done, the alternative hypothesis is accepted which specifies that, "there is a significant difference between the averages of the level of knowledge of English in vocabulary, grammar, interaction and understanding before and after applying the pedagogical process".

In fact, the grades average of students exposed to the research varied from an initial average of 5.44 to a final average of 8.28 . This affirms that there is about a $30.40 \%$ increase in the level of knowledge in the English language once the teaching methodology has been applied.

\section{Results}

To carry out the current research, a pre-test and a post-test were handled as a technique to gather the primary information., Dimitrov and Phillip (2003) explained that this kind of tests allowed the analysis of both the control group and the experimental group results to measure changes produced from the experimental treatment. By then, the T Student test was applied to accept the initial hypothesis and reject the null hypothesis. In turn, this led to the case conclusions and recommendations. Likewise, the information obtained was compared with similar scientific articles, journals, and thesis works to justify and confirm the initial findings of the data analysis. Besides, it promoted the interpretation of EFL students' needs, so the results of this research work granted purposeful alternatives to face the given issues.

To apply the knowledge test to both the control and the experimental groups, the Cambridge test designed for A1 Movers was used. Regularly this exam consists of 6 reading sections, however, for this exam only parts $3,4,5$ were considered since parts 1 and 2 do not have the necessary level of complexity and also part 6 because this corresponds to other ability. Furthermore, this test was conducted through an online program called Liveworksheets and the results were generated in an Excel spreadsheet. The same questionnaire was administered as a post-test to collect the expected results. Then with this information, it was proceeded to obtain the general statistics of each reading section of the test and its representation in tables and bar diagrams, besides, the $P$ value of the means of the groups studied was calculated to contrast the two methodologies used and thus determine which of them achieves better results in EFL students. 


\section{Figure 1}

Reading pre-test

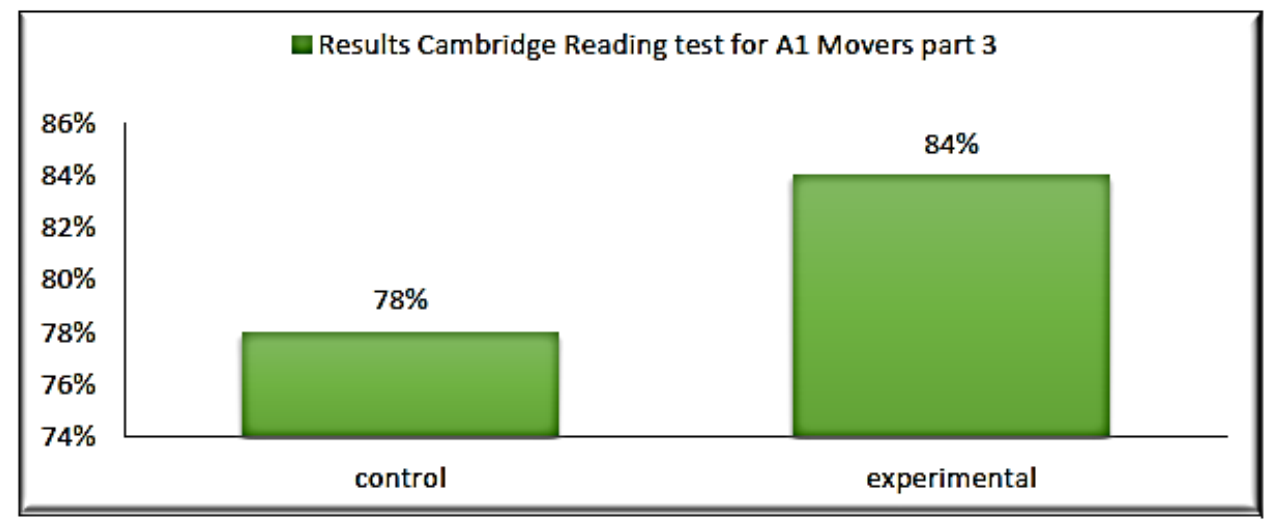

Source: Bautista

The pre-test statistical figure of the Cambridge Reading test for A1 Movers shows a little difference among the experimental group $(2,8 / 3,3)$ in relation to the control group $(2,6 / 3,3)$ in the vocabulary knowledge and ability to decode texts.

Figure 2

Reading post-test

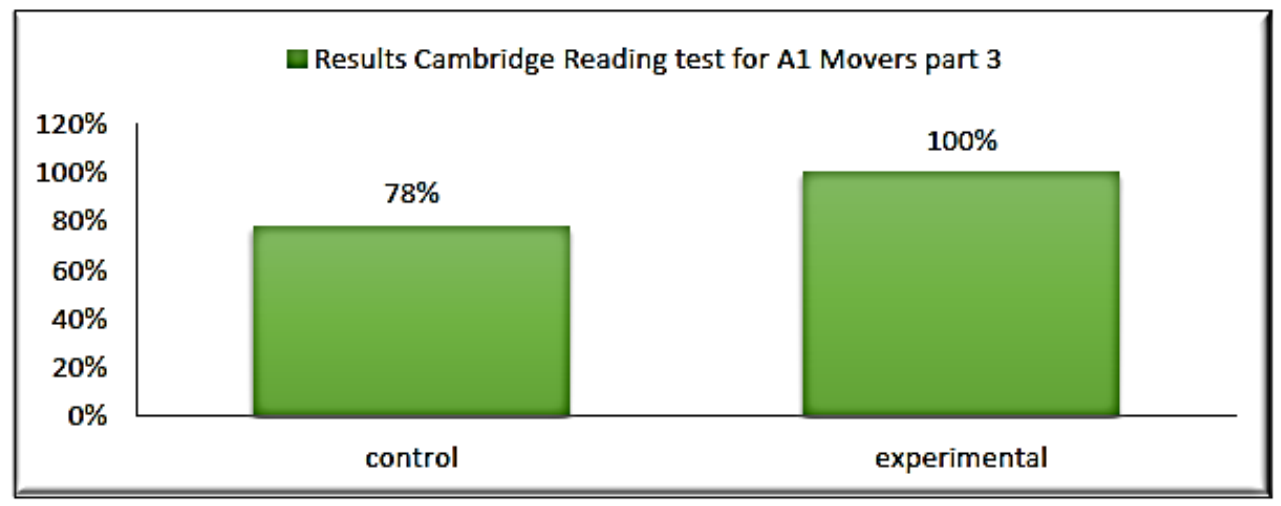

Source: Bautista

The post-test statistical analysis of the Cambridge Reading test for A1 Movers demonstrates a clear difference between the experimental group (3.3/3.3) and the control group (2.6/3.3) in the ability to decode texts and understand words. To illustrate, the control group taught through the conventional reading had an advance, but it was not 
significant as the experimental group. That is, through the literacy circles students increase their lexicon, and more important they learn to interpret words through written clues or graphic representations which are the basis for the development of other reading skills.

Table 1

Paired sample test

Paired differences

95\% confidence
interval of the
difference

Higher

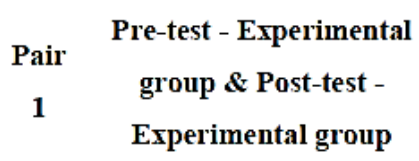

Source: Bautista

This T Student test responds to an analysis of the pre-test scores and the post-test scores, but only of the experimental group (Akyol et al., 2014), this is in order to evidence whether there has been a variation in the level of knowledge, even though the participants had already been part of the new study pedagogy. To consider whether there has been a variation, this $\mathrm{T}$ Student test was applied to the scores obtained by the two groups of students in the post-test. The result of the T Student test for paired samples in the grades obtained is 0.000 . Comparing that score with the evaluation criteria, it is determined that there is a difference between the means of the groups studied. Therefore, the level of knowledge in the final exam for the experimental group has changed. Based on the means of the scores, the student's initial level has grown considerably, so it affirms that the study pedagogy of which these students were part has had a positive effect and has improved the level of understanding the English language.

The following table shows a summary of the means obtained in the entire study of the groups analyzed: 
Table 2

Descriptive statistics

\begin{tabular}{|c|c|c|c|c|c|}
\hline & $\mathbf{N}$ & Minimum & Maximum & Average & $\begin{array}{l}\text { Standard } \\
\text { deviation }\end{array}$ \\
\hline $\begin{array}{c}\text { Pre-test - Control } \\
\text { group }\end{array}$ & 38 & 2,20 & 8,30 & 5,3500 & 1,69622 \\
\hline $\begin{array}{l}\text { Pre-test - Experimental } \\
\text { group }\end{array}$ & 29 & 2,80 & 8,30 & 5,4414 & 1,64523 \\
\hline $\begin{array}{l}\text { Post-test - Control } \\
\text { group }\end{array}$ & 38 & 2,80 & 7,50 & 5,2605 & 1,42706 \\
\hline $\begin{array}{c}\text { Post-test - } \\
\text { Experimental group }\end{array}$ & 29 & 7,20 & 9,50 & 8,2897 & 57777 \\
\hline
\end{tabular}

No. valid (per list)

29

Source: Bautista

\section{Conclusions}

- Through the scores achieved in the initial test, it became evident that the students reading comprehension level is seriously compromised due to the lack of interest in reading and the scarce revision of formal texts. In other words, these situations do not contribute to the consolidation and total mastery of reading skills that are essential within the understanding of different subjects and disciplines.

- According to what could be observed during this intervention, most educators conduct classic reading comprehension strategies such as identifying the main idea and summarizing, answering and asking questions. Teachers use reading strategies in a reflective and flexible manner to promote children reading skills. However, the repetitive use of these strategies is not enough to cover the diverse needs of all students. In short, the scarce updating of teachers in the face of the use of new strategies drives teachers to maintaining and applying the same kind of strategy repeatedly. 
- The relationship between the strategies of literary circles in the development of reading comprehension skills is of great importance as it enables students to learn within a framework of understanding the purposes and objectives of the target text, both the explicit written text and implicit information and facts based on other clues in the story. Likewise, the application of control activities proposed by the teacher and the comprehension of how the literary circles operate can significantly improve the integration of the previous knowledge.

- The main complication that arises in students in the acquisition of skills that allow them to improve their reading comprehension is due to the lack of encouragement to adopt their own reading habits, which does not allow them to adequately relate their current learning to subsequent learning regarding the topic and the subject.

\section{References Bibliographical}

Anderson, P. \& Corbett, L. (2008). Literature Circles for Students with Learning Disabilities. Intervention in School and Clinic, 44(1), 25-33. https://doi.org/10.1177/1053451208318681

Akyol, H., Çakiroğlu, A. \& Kuruyer, H. (2014). A study on the development of reading skills of the students having difficulty in reading: Enrichment reading program. International Electronic Journal of Elementary Education, 6(2), 199-212.

Alvermann, D. \& Earle, J. (2003). Comprehension instruction. Rethinking reading comprehension, 12-30. shorturl.at/cvxz3

Allan, J, Ellis, S. \& Pearson, C. (2005). Literature circles, gender and reading for enjoyment. $\quad$ Seed, 22, 1753-1759. https://www.webarchive.org.uk/wayback/archive/3000/https://www.gov.scot/Re source/Doc/930/0021345.pdf

Briggs, S. (2010). Using Literature Circles to Increase Reading Comprehension in Third Grade Elementary Students. https://eric.ed.gov/?id=ED511091

Coccia, L. (2015). Literature Circles and Their Improvement of Comprehension. In Fisher Digital Publications Education (p. 104). https://fisherpub.sjfc.edu/education_ETD_masters/316/

Dimitrov, M. \& Phillips, D. (2003). Pretest-posttest designs and measurement of change. Work (Reading, Mass.), 20(2), 159-165. 
López, C. (2011). Literature circles: a door to students' life experiences in the classroom. Colombian Applied Linguistics Journal, 9. https://doi.org/10.14483/22487085.3154

Marshall, J. \& Blanton, W. (2006). The effects of participation in literature circles on reading comprehension. https://scholarship.miami.edu/discovery/fulldisplay/alma991031447363602976/ 01UOML_INST:ResearchReposi tory

Medrano, D. \& Diss, E. (2013). An Investigation of Literature Circles to Promote Reading Comprehension (pp. 1-5). Texas Tech University. https://ttuir.tdl.org/bitstream/handle/2346/50624/DiegoMedrano_Elsa_Diss.pdf?sequence $=1$

Mildner, V. (2019). Experimental Research. In I. SAGE Publications (Ed.), SAGE reference (pp. 728-732). https://doi.org/10.4135/9781483380810.n242

Porras, A. (2017). Diplomado en Análisis de Información Geoespacial: Tipo de muestreo. Conacyt, https://centrogeo.repositorioinstitucional.mx/jspui/bitstream/1012/163/1/19Tipos de Muestreo - Diplomado en Análisis de Información Geoespacial.pdf

Snow, C.E., Burns, M.S. \& Griffin, P. (eds.) (1998). Preventing reading difficulties in young children. Washington, DC: National Academy Press, 432 pp. Psychology in the Schools, 39(3), 343-344. https://doi.org/10.1002/pits.10011

\section{Ciencia LDigital}


El artículo que se publica es de exclusiva responsabilidad de los autores y no necesariamente reflejan el pensamiento de la Revista Conciencia Digital.

\section{Ciencia}

El artículo queda en propiedad de la revista y, por tanto, su publicación parcial y/o total en otro medio tiene que ser autorizado por el director de la Revista Conciencia Digital.
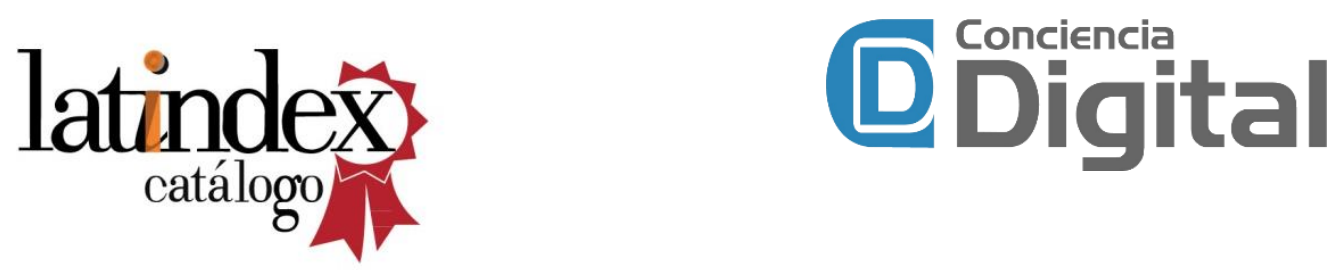

Indexaciones

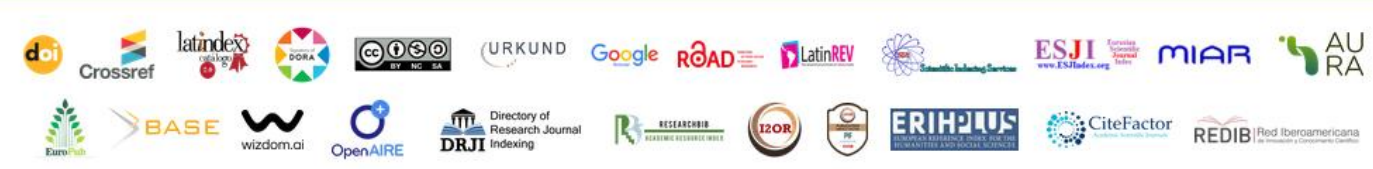

